\title{
Pengolahan Sampah Organik Rumah Tangga Dengan Metode Bata TERAWANG
}

\section{The Treatment Of Household Organic Waste Using Brick Overlay Method}

\author{
${ }^{1}$ Mohamad Satori, ${ }^{2}$ Endang Prastyaningsih, ${ }^{3}$ Yanti Srirejeki, ${ }^{4}$ Tirani Hikmah Nur \\ Ulfah, ${ }^{5}$ Neneng Rika Nurmalasari, ${ }^{6}$ Iik Nuralam \\ ${ }^{1,2,3,4,5,6}$ Fakultas Teknik, Program Studi Teknik Industri, Unisba
}

\begin{abstract}
In Indonesia, the organic waste is the largest type of household waste of $60 \%$ to $70 \%$. Organic waste is potential to be composted, namely as biofertilizer beneficial to plants. Various methods have been developed to process organic waste into compost, one of which is the method of Brick Overlay. This method is practical and easy to do by the community. Community Services activities (PKM) is done for socializing and training processing organic waste using Brick Overlay method to community of $R W 22$ Cipageran Puri Indah 2, Tanimulya Village, Ngamprah District of West Bandung regency. Through the socialization activity, it is found that there has been an increase knowledge of RW 22 community about the types of garbage and how to manage waste materials/trash that environmentally friendly. Even 60\% of community have practiced the result of the training directly.

Keywords: organic waste, compost, brick overlay method, biofertilizer
\end{abstract}

\begin{abstract}
Abstrak.Di Indonesia, sampah organik merupakan jenis sampah rumah tangga dengan komposisi terbesar, yaitu sekitar 60\%-70\%. Sampah organik sangat potensial untuk dijadikan kompos, yaitu sebagai biofertilizer yang sangat bermanfaat bagi tanaman. Berbagai metode telah dikembangkan untuk mengolah sampah organik menjadi kompos, salah satunya adalah dengan metode Bata Terawang. Metode ini merupakan metode yang praktis dan mudah dilakukan oleh masyarakat. Kegiatan Pengabdian Kepada Masyarakat (PKM) ini dilakukan untuk melakukan sosialisasi dan pelatihan pengolahan sampah organik dengan menggunakan metode Bata Terawang kepada masyarakat RW 22 Puri Cipageran Indah 2 Desa Tanimulya Kecamatan Ngamprah Kabupaten Bandung Barat. Dengan adanya sosialisasi didapatkan bahwa telah terjadi peningkatan pengetahuan masyarakat RW 22 tentang jenis-jenis sampah dan tata kelola sampah yang baik dan ramah lingkungan. Bahkan 60\% warga masyarakat telah mempraktekan langsung hasil pelatihan.
\end{abstract}

Kata Kunci : sampah organik, kompos, bata terawang, urban farming, ketahaan pangan 


\section{Pendahuluan}

\section{Analisis Situasi Lokasi Dampingan}

Salah satu RW yang ada Desa Tanimulya, Kecamatan Ngamprah, Kabupaten Bandung Barat adalah RW 22 yang berlokasi di Puri Cipageran Indah 2. Secara administratif RW 22 terdiri atas lima RT dengan jumlah penduduk kurang lebih 800 jiwa dari $250 \mathrm{KK}$, dan memiliki beraneka ragam latar belakang, budaya dan agama.

Sebagai sebuah komunitas masyarakat dengan segala aktifitasnya, maka konsekwensi logisnya adalah adanya timbulan sampah. Bila menggunakan angka timbulan sampah 0,6 kg per orang per hari (Damanhuri, 2005) maka total timbulan sampah di RW 22 diperkirakan 0,48 ton per hari atau sekitar 14,4 ton per bulan. Dengan menggunakan asumsi komposisi sampah organik $60 \%$ maka diperkirakan timbulan sampah organik di RW 22 adalah 0,29 ton per hari atau sekitar 8,64 ton per bulan.

Terkait dengan pengelolaan sampah, pemerintah telah memberlakukan UU 18 tahun 2008 tentang Pengelolaan Sampah. Dalam UU tersebut dikemukakan bahwa pengelolaan sampah dilakukan dengan cara pengurangan dan penanganan. Pengurangan tersebut dilakukan dengan cara (a) melakukan pencegahan, (b) menggunakan ulang, dan (c) mendaur ulang, yang kemudian dikenal dengan istilah 3R (reduce, reuse dan recycle).

Terkait dengan implementasi 3R dalam pengelolaan sampah di RW 22 telah memiliki fasiltas pengolahan sampah baik organik maupun anorganik, walaupun dalam kapasitas yang masih sangat terbatas. Pengolahan sampah organik dilakukan dengan cara pengomposan, biodigester dan biopori, sedangkan sampah anorganik dikelola melalui kegiatan Bank Sampah "Sahdu". Sampah yang terolah saat ini diperkirakan hanya $2 \%$ saja atau sekitar $10 \mathrm{~kg}$ per hari. Sampah yang tidak diolah diangkut oleh petugas kebersihan Dinas Ciptakarya KBB untuk kemudian dibuang ke TPA Sarimukti.

Salah satu teknologi pembuatan kompos yang relatif sederhana dan sangat mudah diaplikasikan oleh masyarakat adalah teknologi Bata Terawang yang berfungsi sebagai komposter. Dengan metode ini potensi sampah organik yang diolah dapat lebih banyak. Teknologi Bata Terawang ini tidak perlu treatment khusus, kecuali pemilahan dan penyiraman bakteri yang telah disediakan. Akan tetapi, metode ini belum tersosialisasikan dengan baik, sehingga tingkat partisipasi masyarakat dalam pemanfaatan bata terawang untuk pengolahan sampah organik masih sangat minim. Saat ini masyarakat yang telah rutin memisahkan sampah organik, kemudian memasukkan sampah organik ke bata terawang hanya sekitar $10 \mathrm{KK}$ dari sekitar 250 KK yang ada di RW 22, atau baru sekitar 4\%. Selain itu pemahaman masyarakat dalam hal pemanfaatan kompos untuk tanaman di pekarangan melalui program urban farming juga masih sangat minim. Oleh karena itu perlu dilakukan upaya untuk lebih mengenalkan komposter Bata Terawang ini dalam proses pengomposan, sehingga program urban farming dapat terwujud.

\section{Permasalahan Mitra}

Sebagaimana telah dikemukakan dalam pendahuluan bahwa penanganan sampah organik di RW 22 dilakukan dengan menerapkan pola pengomposanmenggunakan teknologi Bata Terawang. Namun demikian penerapan teknologi tersebut masih sangat minim. Oleh karena itu permasalahan yang muncul adalah:

1. Persepsi dan pengetahuan masyarakat terkait pemanfaatan bata terawang sebelum dan setelah dilakukan pendampingan; 
Bentuk partisipasi masyarakat dalam hal pemilahan sampah organik dan pengomposan dengan bata terawang;

Pelatihan pemanfaatan kompos untuk mewujudkan urban farming.

\section{Kajian Teoritis}

Dalam Undang Undang No 18 tahun 2008 tentang Pengelolaan Sampah, dikemukakan bahwa sampah adalah sisa kegiatan sehari-hari manusia dan/atau proses alam yang berbentuk padat. Dalam paradigma lama sampah sering hanya dipandang sebagai material sisa yang dihasilkan dari kegiatan manusia yang biasanya dibuang karena sudah tidak digunakan atau dianggap tidak bermanfaat lagi (Tchobanoglous, 2002). Dengan memandang sampah hanya sebagai buangan, maka tanpa pengelolaan yang baik sampah dapat mencemari lingkungan, mengganggu kesehatan lingkungan, mengurangi kenyamanan dan estetika.

Kini, dalam paradigma baru, sampah tidak hanya dipandang sebagai material sisa yang terbuang, akan tetapi juga sebagai sumberdaya (Satori, 2014). Diantara material sampah terdapat potensi sumberdaya yang dapat dibangkitkan kembali (recovery). Sampah organik dapat dikonversi menjadi biofertilizeratau energi (biogas). Untuk material anorganik tertentu dapat didaur ulang menjadi produk yang sama atau produk lain.

Di Indonesia ruang lingkup sampah yang dikelola adalah sebagaimana tercantum dalam Undang-Undang No. 18 tahun 2008 tentang Pengelolaan Sampah, yaitu terdiri dari:

1. Sampah rumah tangga, yaitu sampah yang berasal dari kegiatan sehari-hari dalam rumah tangga, tidak termasuk tinja dan sampah spesifik;

2. Sampah sejenis sampah rumah tangga, yaitu sampah yang berasal dari kawasan komersial, kawasan industri, kawasan khusus, fasilitas sosial, fasilitas umum, dan/atau fasilitas lainnya;

3. Sampah spesifik, yaitu terdiri dari: sampah yang mengandung bahan berbahaya dan beracun, sampah yang mengandung limbah bahan berbahaya dan beracun, sampah yang timbul akibat bencana, puing bongkaran bangunan, sampah yang secara teknologi belum dapat diolah; dan/atau sampah yang timbul secara tidak periodik.

Dilihat dari karakteristik fisik-kimianya, sampah terbagi dalam dua golongan, yaitu : sampah organik, dan sampah anorganik. Sampah organik merupakan jenis sampah dengan komposisi paling besar untuk sampah rumah tangga terutama di negaranegara berkembang. Komposisi sampah organik (decomposable organic waste) di negara berkembang antara 42\% - 80,2\% (Dhokhikah, 2012). Sementara itu di Indonesia, menurut Kementrian Pekerjaan Umum komposisi sampah organik mencapai $70 \%$, anorganik 28\% dan sampah B3 (bahan berbahaya dan beracun) sekitar 2\% (Damanhuri, 2005). Penelitian lain terkait komposisi sampah organik di Indonesia sekitar $80 \%$ dan diperkirakan $78 \%$ dari sampah tersebut dapat dimanfaatkan kembali (Outerbridge, ed., 1991 dalam Sulistyorini, 2005).

Sampah organik umumnya merupakan sampah yang terdiri dari sampah dapur, sisa makanan, kulit buah dan sampah taman, yang mudah hancur dan mudah terurai. Secaraalami,sampah organik mengalami pembusukan atau penguraian oleh mikrobaatau jasad renik seperti bakteri, jamur dan sebagainya. Pada proses penguraiantersebut dibutuhkan kondisi lingkungan yang optimal agar semakin cepat atau semakin baik mutukomposnya (Ardiningtyas, 2013). 
Sesuai karakteristik fisik, kimia dan biologi tersebut, maka sampah organik dapat ditranfomasi menjadi kompos, yaitu biovertilizer yang dapat berfungsi untuk menambah unsur hara dalam tanah. Proses transformasi sampah organik menjadi kompos dilakukan dengan memanfaatkan jasad renik/bakteri baik yang ada dalam sampah organik itu sendiri maupun tambahan dari luar.

Samekto (2006) mengemukakan bahwa pengomposan merupakan proses dekomposisi terkendali secara biologis terhadap limbahpadat organik dalam kondisi aerobik (terdapat oksigen) atau anaerobik (tanpa oksigen).Kondisi yang terkendali tersebut meliputi rasio karbon dan nitrogen $(\mathrm{C} / \mathrm{N}$ ratio), kelembaban, $\mathrm{pH}$, dan kebutuhan oksigen (Samekto, 2006:24).

Proses pembuatan kompos secara umum dibagi dalam dua cara, yaitu proses secara aerobik dan anaerobik. Pengomposan secara aerobik adalah modifikasi yangterjadi secara biologis pada struktur kimia atau biologi bahan organik dengan kehadiranoksigen. Dalam proses ini banyak koloni bakteri yang berperan misalnya: bakteriPhsycrophile, mesofilik, dan termofilik (Samekto, 2006).Mikroorganisme mengambil air dan oksigen dari udara sedangkan makanan diperolehdari hasil dekomposisi bahan organik secara aerobik (Samekto, 2006). Selanjutnya menurut Samekto (2006), sebagian energi yang dihasilkan digunakan oleh mikroorganisme untukpertumbuhan dan reproduksi sedangkan sisanya dibebaskan ke lingkungan sebagai panas.Hasil dari proses pengomposan secara aerobik adalah $\mathrm{CO}^{2}, \mathrm{H}^{2} \mathrm{O}$ (air), humus, dan energi.

Sementara itu pengomposan anaerobik merupakan modifikasi biologis pada struktur kimia danbiologi bahan organik tanpa kehadiran oksigen (Samekto, 2006). Pada prosespengomposan ini tidak terjadi fluktuasi suhu seperti halnya yang terjadi pada pengomposanaerobik. Proses pengomposan secara anaerobik akanmenghasilkan metana (alkohol), $\mathrm{CO}^{2}$, dan senyawa lain seperti asam organik yang memilikiberat molekul rendah (asam asetat, asam propionat, asam butirat, dan asam laktat) (Samekto, 2006).

\section{Metode Pelaksanaan}

Proses pemberdayaan masyarakat dilakukan dengan pendekatan Participatory Learning and Action (PLA)/Participatory Rural Appraisal (PRA). Secara umum proses pelaksanaan PRA/PLA adalah sbb:

\section{Kunjungan awal dan pengakraban diri dengan masyarakat}

1. Kunjungan awal ini bertujuan untuk:membangun kepercayaan, keterbukaan, dan keakraban; mengembangkan rencana pelaksanaan PRA/PLA bersama masyarakat; serta memberi gambaran lebih lengkap secara bersama terkait rencana kegiatan.

2. Waktu kunjungan awaltim PKM dilaksanakan menjelang pelaksanaan kegiatan pendampingan

3. Dalam kunjungan awal ini ditentukan lokasi pembuatan bata terawang dan jadwal pelaksanaan pelatihan.

4. Catatan dan anjuran

a. Perlu memberi perhatian khusus pada kaum perempuan dan remaja yang sering ditinggalkan, jelaskan ke semua kelompok mengapa perempuan dan remaja perlu dilibatkan

b. Di sela-sela kegiatan, adakan hiburan, lelucon, dan sebagainya 
c. Gunakan teknik "melakukan sendiri" untuk menyelami kehidupan seharihari masyarakat

d. Ajak semua yang hadir untuk berpartisipasi

\section{Pelaksanaan}

1. Integrasi

Integrasi adalah tahap masuknya seorang pendamping ke dalam suatu komunitas yang sama sekali belum didatangi oleh pendamping.

2. Adaptasi

Tahap ini merupakan tahap diterimanya pendamping oleh masyarakat yang akan didampingi.

3. Inventarisasi Masalah

Tahap ini merupakan tahap pengumpulan berbagai informasi tentang segala persoalan yang dihadapi masyarakat di samping informasi tentang potensi yang dimiliki, baik potensi alam, SDM, maupun sumber daya sosialnya.

4. Problematisasi Masalah

Berdasarkan persoalan yang telah diinventarisasi, maka pendamping melakukan tahap pengembalian masalah melalui proses problematisasi masalah.

\section{Aksi}

Tahap ini merupakan tahapan untuk memberdayakan masyarakat terutama dari pengembangan sikap. Pemberdayaan dimulai dari kegiatan yang dianggap mampu untuk dilakukan dan memiliki tingkat keberhasilan cukup besar. Karenanya, sebaiknya kegiatan dimulai dari yang kecil, sederhana, namun konkret dan melibatkan banyak orang.

6. Evaluasi

Tahap ini merupakan tahap penilaian tentang apa yang telah dilakukan bersamasama untuk melakukan perbaikan pada kegiatan selanjutnya.

\section{Refleksi}

Tahap ini merupakan tahap untuk melakukan introspeksi tentang segala sesuatu yang sudah dilakukan mulai dari tahap awal sampai kepada evaluasi. Evaluasi meliputi semua aspek, yaitu pelaku, program, maupun kondisi sosial lingkungan yang turut mempengaruhi proses secara keseluruhan. Berdasarkan tahap refleksi ini, pendamping bersama-sama dengan masyarakat mulai melakukan kegiatan berikutnya yang dianggap perlu dilakukan, misalnya pada kegiatan berikutnya, dapat saja ditingkatkan volume dan bentuk kegiatannya.

Gambar 1 menunjukkan skema metodologi pendampingan. 
A. Kunjungan awal dan pengakraban diri dengan masyarakat

1. Tujuan kunjungan awal

2. Waktu kunjungan awal

3. Langkah-langkah kunjungan awal

4. Catatan dan aniuran (1)

B. Tahap Pelaksanaan

1. Integrasi

2. Adaptasi

3. Inventarisasi masalah

4. Problematisasi masalah

5. Aksi

6. Evaluasi

7. Refleksi

\section{Gambar 1. Metodologi Pendampingan}

\section{Hasil Dan Pembahasan}

\section{KAP Survey}

Salah satu indikator yang digunakan sebelum maupun setelah dilakukan pendampingan adalah berkaitan dengan pengetahuan (knowledge), sikap (attitude), dan perilaku (practice) yang kemudian disebut KAP survey. Survey ini dilakukandengan menyebarkan kuesionerkepada semua peserta yang mengikuti kegiatan pelatihan dan pendampingan pengolahan sampah organik dengan bata terawang. Tujuan dilakukannya survey tersebut adalah untuk mengetahui bagaimana pengetahuan, sikap dan tindakan mereka terkait dengan pengelolaan sampah terutama sampah organic. Hasil survey baik sebelum maupun setelah dilakukan pendampingan tersebut terangkum dalam Tabel 1, 2 dan 3 .

Tabel 1. Knowledge (Pengetahuan)

\begin{tabular}{|c|c|c|c|c|c|}
\hline \multirow{3}{*}{ No } & \multirow{3}{*}{ Pertanyaan } & \multicolumn{4}{|c|}{ Jawaban } \\
\hline & & \multicolumn{2}{|c|}{ Sebelum } & \multicolumn{2}{|c|}{ Sesudah } \\
\hline & & Tahu & $\begin{array}{l}\text { Tdk } \\
\text { tahu }\end{array}$ & Tahu & $\begin{array}{l}\text { Tdk } \\
\text { tahu }\end{array}$ \\
\hline 1. & $\begin{array}{l}\text { Pengelola sampah di KBB termasuk di RW } 22 \text { dilakukan } \\
\text { oleh UPT Kebersihan Dinas Ligkungan Hidup KBB? }\end{array}$ & $75 \%$ & $25 \%$ & $100 \%$ & $0 \%$ \\
\hline 2. & $\begin{array}{l}\text { Peranserta masyarakat merupakan bagian dari sistem } \\
\text { pengelolaan sampah sesuai peraturan perundang-undangan } \\
\text { yang ada? }\end{array}$ & $90 \%$ & $10 \%$ & $100 \%$ & $0 \%$ \\
\hline 3. & $\begin{array}{l}\text { Pemerintah dan masyarakat (RT/RW) berbagi peran/tugas } \\
\text { dalam mengelola sampah? }\end{array}$ & $100 \%$ & $0 \%$ & $100 \%$ & $0 \%$ \\
\hline 4. & $\begin{array}{l}\text { Pengelolaan sampah terdiri dari pengurangan (reduce, } \\
\text { reuse, recycle) dan penanganan (pilah, kumpul, angkut, } \\
\text { proses akhir) }\end{array}$ & $100 \%$ & $0 \%$ & $100 \%$ & $0 \%$ \\
\hline 5. & $\begin{array}{l}\text { Pengurangan sampah sebagaimana diatur dalam UU } 18 \\
\text { tahun } 2008 \text { adalah wajib }\end{array}$ & $67 \%$ & $33 \%$ & $100 \%$ & $0 \%$ \\
\hline
\end{tabular}




\begin{tabular}{|c|c|c|c|c|c|}
\hline \multirow{3}{*}{ No } & \multirow{3}{*}{ Pertanyaan } & \multicolumn{4}{|c|}{ Jawaban } \\
\hline & & \multicolumn{2}{|c|}{ Sebelum } & \multicolumn{2}{|c|}{ Sesudah } \\
\hline & & Tahu & $\begin{array}{l}\text { Tdk } \\
\text { tahu }\end{array}$ & Tahu & $\begin{array}{l}\text { Tdk } \\
\text { tahu }\end{array}$ \\
\hline 6. & $\begin{array}{l}\text { Pengelolaan sampah di RW } 22 \text { dilakukan dengan pola 3R } \\
\text { (Reduce, Reuse, Recycle)? }\end{array}$ & $86 \%$ & $14 \%$ & $100 \%$ & $0 \%$ \\
\hline 7. & $\begin{array}{l}\text { RW } 22 \text { memiliki Saung dan Taman Edukasi 3R sebagai } \\
\text { tempat belajar mengolah dan memanfaatkan sampah? }\end{array}$ & $95 \%$ & $5 \%$ & $100 \%$ & $0 \%$ \\
\hline 8. & $\begin{array}{l}\text { RW } 22 \text { memiliki taman organik yang terdiri dari tanaman } \\
\text { sayur mayur dan obat keluarga yang dapat dimanfaatkan } \\
\text { warga secara gratis }\end{array}$ & $100 \%$ & $0 \%$ & $100 \%$ & $0 \%$ \\
\hline 9. & $\begin{array}{l}\text { RW } 22 \text { telah memiliki Bank Sampah Sahdu yang dapat } \\
\text { menampung tabungan sampah bahan daur ulang dari } \\
\text { warga sekitar }\end{array}$ & $90 \%$ & $10 \%$ & $100 \%$ & $0 \%$ \\
\hline 10. & $\begin{array}{l}\text { Di wilayah RW } 22 \text { telah tersedia "bata terawang" sebagai } \\
\text { sarana pengolahan sampah organik menjadi kompos yang } \\
\text { tersebar di setiap RT. }\end{array}$ & $81 \%$ & $19 \%$ & $100 \%$ & $0 \%$ \\
\hline 11. & $\begin{array}{l}\text { Sampah yang berasal dari dapur atau halaman seperti } \\
\text { daun-daun merupakan sampah organik/sampah basah? }\end{array}$ & $95 \%$ & $5 \%$ & $100 \%$ & $0 \%$ \\
\hline 12. & $\begin{array}{l}\text { Sampah organik seperti sisa makanan dan daun-daunan } \\
\text { yang anda hasilkan dapat diolah menjadi kompos? }\end{array}$ & $100 \%$ & $0 \%$ & $100 \%$ & $0 \%$ \\
\hline 13. & $\begin{array}{l}\text { Sampah seperti neon/lampu bekas, batu batere bekas, } \\
\text { pempers, embalut, merupakan sampah B3 (Bahan } \\
\text { Berbahaya dan beracun/B3)? }\end{array}$ & $90 \%$ & $10 \%$ & $100 \%$ & $0 \%$ \\
\hline 14. & $\begin{array}{l}\text { Sampah jenis anorganik seperti logam, plastik, kertas dapat } \\
\text { didaur ulang menjadi produk tertentu? }\end{array}$ & $90 \%$ & $10 \%$ & $100 \%$ & $0 \%$ \\
\hline 15. & $\begin{array}{l}\text { Sampah kemasan seperti bungkus kopi, kresek, dll dapat } \\
\text { diolah menjadi produk-produk kerajinan }\end{array}$ & $100 \%$ & $0 \%$ & $100 \%$ & $0 \%$ \\
\hline 16. & $\begin{array}{l}\text { Membakar sampah dilarang berdasarkan UU } 18 \text { tahun } \\
2008 \text {. }\end{array}$ & $60 \%$ & $40 \%$ & $80 \%$ & $20 \%$ \\
\hline
\end{tabular}

\section{Tabel 2.Attitude (Sikap)}

\begin{tabular}{|c|c|c|c|c|c|c|c|}
\hline \multirow[b]{2}{*}{ No } & \multirow[b]{2}{*}{ Pertanyaan } & \multicolumn{6}{|c|}{ Jawaban } \\
\hline & & & $\begin{array}{l}\text { Sangat } \\
\text { setuju }\end{array}$ & Setuju & $\begin{array}{c}\text { Kurang } \\
\text { setuju }\end{array}$ & $\begin{array}{l}\text { Tidak } \\
\text { setuju }\end{array}$ & Abstain \\
\hline \multirow[t]{2}{*}{1.} & \multirow{2}{*}{$\begin{array}{l}\text { Saya lebih suka jika pengelolaan sampah di } \\
\text { lingkungan rumah dilakukan oleh warga } \\
\text { setempat/petugas RT/RW secara } \\
\text { bergantian/gotong royong sampai ke Tempat } \\
\text { Penampungan Sementara (TPS) daripada } \\
\text { dilakukan oleh petugas kebersihan KBB }\end{array}$} & $\frac{\Xi}{n}$ & $24 \%$ & $57 \%$ & $19 \%$ & $0 \%$ & $0 \%$ \\
\hline & & $\begin{array}{l}\tilde{0} \\
\tilde{n} \\
\tilde{\Omega}\end{array}$ & $24 \%$ & $71 \%$ & $5 \%$ & $0 \%$ & $0 \%$ \\
\hline \multirow[t]{2}{*}{2.} & \multirow{2}{*}{$\begin{array}{l}\text { Saya lebih suka jika pengelolaan sampah } \\
\text { dilakukan dengan cara diangkut dan dibuang } \\
\text { ke TPA semuanya oleh petugas kebersihan } \\
\text { daripada sebagian diolah baik sendiri } \\
\text { maupun secara kolektif di RT/RW. }\end{array}$} & $\frac{\Xi}{\tilde{n}}$ & $14 \%$ & $10 \%$ & $48 \%$ & $29 \%$ & $0 \%$ \\
\hline & & 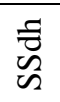 & $0 \%$ & $0 \%$ & $48 \%$ & $52 \%$ & $0 \%$ \\
\hline
\end{tabular}




\begin{tabular}{|c|c|c|c|c|c|c|c|}
\hline \multirow[b]{2}{*}{ No } & \multirow[b]{2}{*}{ Pertanyaan } & \multicolumn{6}{|c|}{ Jawaban } \\
\hline & & & $\begin{array}{l}\text { Sangat } \\
\text { setuju }\end{array}$ & Setuju & $\begin{array}{c}\text { Kurang } \\
\text { setuju }\end{array}$ & $\begin{array}{l}\text { Tidak } \\
\text { setuju }\end{array}$ & Abstain \\
\hline \multirow[t]{2}{*}{3.} & \multirow{2}{*}{$\begin{array}{l}\text { Saya lebih suka menempatkan sampah } \\
\text { sampah tercampur dalam satu wadah } \\
\text { daripada terpilah terutama antara sampah } \\
\text { basah (organik) dan sampah kering } \\
\text { (anorganik). }\end{array}$} & $\frac{\Xi}{n}$ & $5 \%$ & $19 \%$ & $33 \%$ & $43 \%$ & $0 \%$ \\
\hline & & $\begin{array}{l}\tilde{0} \\
\tilde{\approx} \\
\tilde{\Omega}\end{array}$ & $0 \%$ & $0 \%$ & $38 \%$ & $62 \%$ & $0 \%$ \\
\hline \multirow[t]{2}{*}{4.} & \multirow{2}{*}{$\begin{array}{l}\text { Saya lebih suka memasukkan sampah } \\
\text { organik ke biopori/komposter bata terawang } \\
\text { terdekat /komposter lainnya daripada } \\
\text { membuang ke tempat sampah depan rumah }\end{array}$} & $\begin{array}{l}\frac{\Xi}{0} \\
\tilde{n}\end{array}$ & $33 \%$ & $62 \%$ & $0 \%$ & $0 \%$ & $5 \%$ \\
\hline & & $\begin{array}{l}\tilde{\theta} \\
\mathscr{N} \\
\approx\end{array}$ & $60 \%$ & $40 \%$ & $0 \%$ & $0 \%$ & $0 \%$ \\
\hline \multirow[t]{2}{*}{5.} & \multirow{2}{*}{$\begin{array}{l}\text { Bila saya mempunyai halaman dengan } \\
\text { banyak pepohonan, maka saya lebih suka } \\
\text { mengubur daun-daun yang jatuh dari pada } \\
\text { membakarnya di halaman/menyatukannya } \\
\text { dengan sampah lain. }\end{array}$} & $\frac{\Xi}{2}$ & $19 \%$ & $62 \%$ & $14 \%$ & $5 \%$ & $0 \%$ \\
\hline & & $\begin{array}{l}\tilde{D} \\
\tilde{n} \\
\tilde{n}\end{array}$ & $47 \%$ & $48 \%$ & $5 \%$ & $0 \%$ & $0 \%$ \\
\hline \multirow[t]{2}{*}{6.} & \multirow{2}{*}{$\begin{array}{l}\text { Saya lebih suka menyimpan sampah sisa } \\
\text { makanan dalam tempat terpisah dari pada } \\
\text { menyatukannya dengan sampah lain karena } \\
\text { membuat sampah lain menjadi basah. }\end{array}$} & $\frac{\Xi}{n}$ & $19 \%$ & $62 \%$ & $10 \%$ & $10 \%$ & $0 \%$ \\
\hline & & $\begin{array}{l}\tilde{\theta} \\
\tilde{\sim} \\
\tilde{\Omega}\end{array}$ & $24 \%$ & $76 \%$ & $0 \%$ & $0 \%$ & $0 \%$ \\
\hline \multirow[t]{2}{*}{7.} & \multirow{2}{*}{$\begin{array}{l}\text { Saya lebih suka meyimpan kertas bekas/dus- } \\
\text { dus bekas yang masih bisa dipakai daripada } \\
\text { membuangnya ke tempat sampah. }\end{array}$} & $\begin{array}{l}\text { E } \\
\text { ह }\end{array}$ & $14 \%$ & $67 \%$ & $5 \%$ & $10 \%$ & $5 \%$ \\
\hline & & $\begin{array}{l}5 \\
0 \\
n\end{array}$ & $18 \%$ & $82 \%$ & $0 \%$ & $0 \%$ & $0 \%$ \\
\hline \multirow[t]{2}{*}{8.} & \multirow{2}{*}{$\begin{array}{l}\text { Bila ada plastik kresek bekas /plastik bekas } \\
\text { pembungkus saya lebih suka membuangnya } \\
\text { daripada menyimpannya untuk keperluan } \\
\text { lain atau disetorkan ke Bank Sampah. }\end{array}$} & $\frac{\Xi}{2}$ & $0 \%$ & $29 \%$ & $33 \%$ & $33 \%$ & $5 \%$ \\
\hline & & $\begin{array}{l}\tilde{0} \\
\tilde{D} \\
\tilde{n}\end{array}$ & $0 \%$ & $0 \%$ & $45 \%$ & $55 \%$ & $0 \%$ \\
\hline \multirow[t]{2}{*}{9.} & \multirow{2}{*}{$\begin{array}{l}\text { Saya lebih suka membeli makanan/minuman } \\
\text { dari kemasan botol/kaleng yang dapat } \\
\text { ditukar walaupun harus menyimpannya } \\
\text { daripada membeli kemasan plastik yang } \\
\text { langsung buang. }\end{array}$} & $\begin{array}{l}\Xi \\
\tilde{D} \\
\end{array}$ & $10 \%$ & $62 \%$ & $19 \%$ & $5 \%$ & $5 \%$ \\
\hline & & $\begin{array}{l}\text { F } \\
\text { ص } \\
\tilde{n}\end{array}$ & $25 \%$ & $75 \%$ & $0 \%$ & $0 \%$ & $0 \%$ \\
\hline \multirow[t]{2}{*}{10.} & \multirow{2}{*}{$\begin{array}{l}\text { Saya lebih suka memberikan/menjual } \\
\text { sampah bahan daur ulang ke pemulung } \\
\text { tukang rongsok daripada ke Bank Sampah } \\
\text { Sahdu. }\end{array}$} & $\frac{\Xi}{n}$ & $5 \%$ & $29 \%$ & $43 \%$ & $24 \%$ & $5 \%$ \\
\hline & & $\begin{array}{l}\tilde{\theta} \\
\tilde{N} \\
\tilde{\Omega}\end{array}$ & $0 \%$ & $0 \%$ & $65 \%$ & $35 \%$ & $0 \%$ \\
\hline
\end{tabular}

Tabel 3. Practice (Perilaku)

\begin{tabular}{|c|c|c|c|c|c|c|c|}
\hline \multirow[b]{2}{*}{ No } & \multirow[b]{2}{*}{ Pertanyaan } & \multicolumn{6}{|c|}{ Jawaban } \\
\hline & & & Selalu & Sering & $\begin{array}{l}\text { Kadang- } \\
\text { kadang }\end{array}$ & $\begin{array}{c}\text { Tdk } \\
\text { pernah }\end{array}$ & Abstain \\
\hline \multirow[t]{2}{*}{1.} & \multirow{2}{*}{$\begin{array}{l}\text { Saya menyimpan sampah secara terpilah } \\
\text { (organik, anorganik dan B3) di rumah agar } \\
\text { sampah memudahkan dalam proses daur } \\
\text { ulang baik oleh diri sendiri maupun } \\
\text { dilakukan dalam skala RW dan kawasan }\end{array}$} & $\frac{\Xi}{0}$ & $29 \%$ & $19 \%$ & $33 \%$ & $14 \%$ & $5 \%$ \\
\hline & & $\begin{array}{l}\tilde{F} \\
\tilde{D} \\
\approx\end{array}$ & $60 \%$ & $40 \%$ & $0 \%$ & $0 \%$ & $0 \%$ \\
\hline 2. & $\begin{array}{l}\text { Saya/keluarga saya menyetor sendiri } \\
\text { sampah bahan daur ulang dari rumah ke }\end{array}$ & $\frac{\Xi}{0}$ & $19 \%$ & $5 \%$ & $43 \%$ & $24 \%$ & $10 \%$ \\
\hline
\end{tabular}




\begin{tabular}{|c|c|c|c|c|c|c|c|}
\hline \multirow[b]{2}{*}{ No } & \multirow[b]{2}{*}{ Pertanyaan } & \multicolumn{6}{|c|}{ Jawaban } \\
\hline & & & Selalu & Sering & $\begin{array}{l}\text { Kadang- } \\
\text { kadang }\end{array}$ & $\begin{array}{l}\text { Tdk } \\
\text { pernah }\end{array}$ & Abstain \\
\hline & Bak sampah di lingkungan RT/RW saya. & $\begin{array}{l}\tilde{0} \\
\tilde{\omega}\end{array}$ & $74 \%$ & $26 \%$ & $0 \%$ & $0 \%$ & $0 \%$ \\
\hline \multirow[t]{2}{*}{3.} & \multirow[t]{2}{*}{$\begin{array}{l}\text { Saya menyapu dan mengumpulkan sampah } \\
\text { dari jalan di depan rumah saya. }\end{array}$} & $\frac{\Xi}{2}$ & $71 \%$ & $14 \%$ & $10 \%$ & $0 \%$ & $5 \%$ \\
\hline & & $\begin{array}{l}\frac{1}{D} \\
\mathscr{\sim} \\
\tilde{n}\end{array}$ & $75 \%$ & $25 \%$ & $0 \%$ & $0 \%$ & $0 \%$ \\
\hline \multirow[t]{2}{*}{4.} & \multirow{2}{*}{$\begin{array}{l}\text { Saya/keluarga saya membayar } \\
\text { iuran/retribusi sampah melalui RT/RW } \\
\text { setiap bulan. }\end{array}$} & $\frac{\Xi}{0}$ & $90 \%$ & $5 \%$ & $0 \%$ & $0 \%$ & $5 \%$ \\
\hline & & $\begin{array}{l}\tilde{F} \\
\tilde{\mathscr{n}} \\
\tilde{\sim}\end{array}$ & $95 \%$ & $5 \%$ & $0 \%$ & $0 \%$ & $0 \%$ \\
\hline \multirow[t]{2}{*}{5.} & \multirow{2}{*}{$\begin{array}{l}\text { Sampah yang berasal dari dapur dan taman } \\
\text { diolah sendiri baik menggunakan biopori, } \\
\text { komposter atau dimasukkan ke komposter } \\
\text { bata terawang. }\end{array}$} & $\frac{\Xi}{2}$ & $29 \%$ & $14 \%$ & $5 \%$ & $38 \%$ & $14 \%$ \\
\hline & & $\begin{array}{l}\frac{F}{0} \\
\approx\end{array}$ & $44 \%$ & $56 \%$ & $0 \%$ & $0 \%$ & $0 \%$ \\
\hline \multirow[t]{2}{*}{6.} & \multirow{2}{*}{$\begin{array}{l}\text { Saya menyimpan sampah } \\
\text { plastik/kaleng/dus yang masih bagus untuk } \\
\text { dipakai kembali atau untuk di jual ke } \\
\text { tukang rongsok }\end{array}$} & $\frac{\Xi}{n}$ & $14 \%$ & $14 \%$ & $43 \%$ & $24 \%$ & $5 \%$ \\
\hline & & $\begin{array}{l}f \\
\tilde{D} \\
\tilde{\varkappa}\end{array}$ & $60 \%$ & $40 \%$ & $0 \%$ & $0 \%$ & $0 \%$ \\
\hline \multirow[t]{2}{*}{7.} & \multirow{2}{*}{$\begin{array}{l}\text { Saya/keluarga saya menggunakan kembali } \\
\text { kertas bekas koran/majalah untuk } \\
\text { pembungkus atau untuk keperluan lainnya }\end{array}$} & $\frac{\Xi}{2}$ & $10 \%$ & $19 \%$ & $52 \%$ & $14 \%$ & $5 \%$ \\
\hline & & $\begin{array}{l}\frac{1}{D} \\
\mathscr{\varkappa}\end{array}$ & $71 \%$ & $29 \%$ & $0 \%$ & $0 \%$ & $0 \%$ \\
\hline \multirow[t]{2}{*}{8.} & \multirow[t]{2}{*}{$\begin{array}{l}\text { Saya menyetorkan sampah bahan daur } \\
\text { ulang ke Bank Sampah Sahdu }\end{array}$} & $\frac{\Xi}{2}$ & $19 \%$ & $14 \%$ & $19 \%$ & $29 \%$ & $19 \%$ \\
\hline & & $\begin{array}{l}f \\
\tilde{D} \\
\tilde{2}\end{array}$ & $60 \%$ & $40 \%$ & $0 \%$ & $0 \%$ & $0 \%$ \\
\hline
\end{tabular}

Dari hasil survey tersebut terhadap semua peserta yang mengikuti pelatihan secara umum dari sisi pengetahuan terutama pengetahuan tentang sampah organik sangat baik, dan untuk sampah anorgani 100\% mereka mengetahui. Begitu pula pengetahuan mereka terkait dengan keberadaan bata terwang yang sudah terpasang di beberapa tempat di lingkungan RW 22 juga sudah cukup baik yaitu sekitar $81 \%$ mengetahui. Namun demikian pengetahuan yang baik belum tentu seiring dengan sikap dan perilaku sehari-hari. Sikap mereka yang setuju untuk mengolah sampah organik adalah $62 \%$. Kemudian dalam prakteknya peserta yang mengolah sampah organik yang mejawab selalu 29\%, yang menjawab sering $19 \%$ dan yang kadang-kadang 5\%. Dengan demikian maka dalam PKM ini tepat kiranya porsi kegiatan praktek baik memilah maupun proses pembuatan kompos lebih ditonjolkan.

\section{Pembuatan Bata Terawang}

Teknologi bata terawang adalah sebuah metode pengomposan sampah organik dengan menggunakan prinsip aerobik, yaitu pengomosan dengan oksigen untuk aerasi. Komposter Bata Terawang terbuat dari batu bata yang disusun tanpa lapisan semen. Penemu komposter bata terawang adalah Bapak Sobirin yang mengembangkan komposter tersebut di rumahnya yaitu Jl. Alfa No. 92 Cigadung II Kota Bandung. Komposter tersebut dinamakan bata terawang karena terbuat dari susunan bata merah yang disusun dengan jarak tertentu antar bata sehingga bisa diterawang. Lubang-lubang 
tersebut berfungsi sebagai aerasi atau udara yang dibutuhkan untuk hidupnya bakteri aerob (http://clearwaste.blogspot.co.id/2007/08/asyiknya-panen-kompos.html, diakses tanggal 28 Agustus 2017 pukul 16.50).

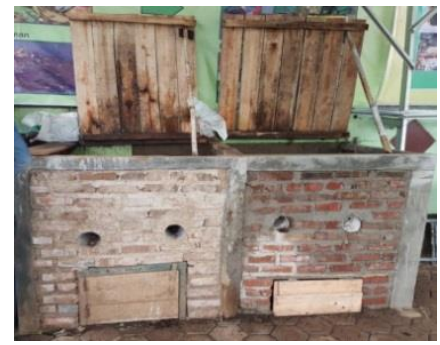

\section{Gambar 2. Konstruksi Komposter Bata Terawang}

\section{Hasil Dampingan}

Evaluasihasil pendampingandilakukan dengan dua cara, yaitu menyebarkan kuesioner kembali kepada para peserta yang mengikuti pelatihan dan dampingan, kemudian melakukan kunjungan ke tempat tinggal masing-masing yang dipilih secara acak untuk melihat aktifitas pasca pelatihan dan dampingan.

Berdasarkan hasil evaluasi melalui penyebaran kuesioner yang ditunjukkan oleh Tabel 1,2 dan 3, terlihat ada perubahan pada pengetahuan, sikap maupun praktek. Beberapa hal yang terlihat perubahannya antara lain adalah sebagai berikut:

1. Pengetahuanpeserta tentang keberadaan komposter bata terawang di wilayah RW 22 meningkat dari $81 \%$ menjadi $100 \%$.

2. Pengetahuan peserta tentang sampah dapur dan dedaunan adalah jenis sampah organik meningkat dari $95 \%$ menjadi $100 \%$

3. Sikappeserta dalam hal membuang sampah secara terpisah semula hanya $43 \%$ kemudian meningkat menjadi $100 \%$

4. Sikap masyarakat untuk mengolah sampah organik dengan bata terawang meningkat dari 33\% menjadi $60 \%$.

Kemudian dilihat dari pengamatan lapangan terlihat ada beberapa perubahan perilaku masyarakat baik dalam hal memilah sampah, memanfaatkan sampah organik menjadi kompos maupun pemanfaatan kompos untuk urban farming. Beberapa kegiatan yang terlihat di lapangan diperlihatkan dalam Gambar 3.

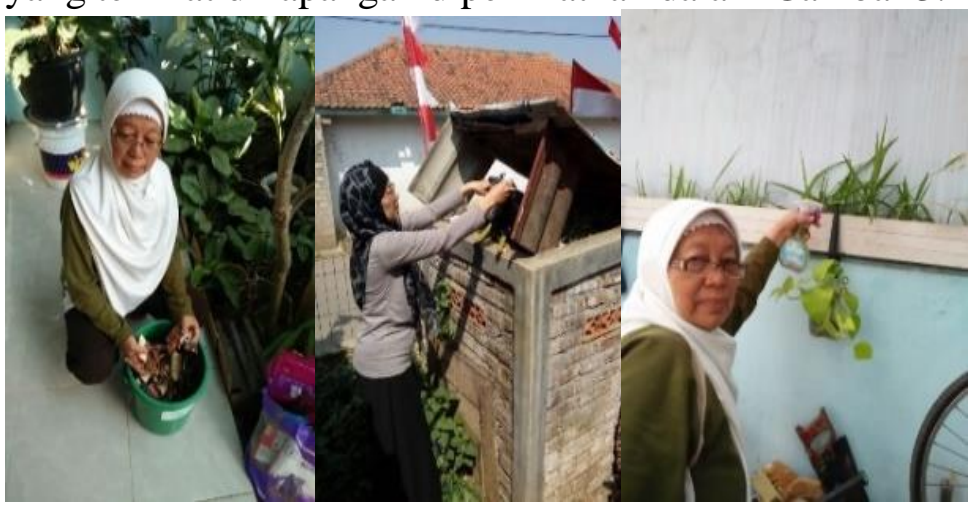

Gambar 3. Kegiatan Warga Pasca Pelatihan dan Dampingan

\section{Kesimpulan}

Berdasarkan evaluasi dari seluruh rangkaian kegiatan PKM yang telah dilakukan, maka dapat disimpulkan beberapa hal sebagai berikut: 
1. Pengetahuan para peserta pada umumnya meningkat, berkaitan dengan tata kelola sampah yang baik dan ramah lingkungan maupun terkait dengan pengetahuan jenis sampah termasuk sampah organik. Para peserta sudah mengetahui bahwa peraturan perundang-undangan di Indonesia telah mengatur hal tersebut.

2. Pengetahuan masyarakat dalam pengolahan sampah organik meningkat, tidak hanya mengetahui saja tetapi masyarakat sudah mulai mempraktekannya. Berdasarkan hasil survey setelah kegiatan pengabdian dilakukan, hal pemilahan misalnya, pengetahuan mereka hampir $100 \%$ paham dan dalam prakteknya sudah meningkat menjadi $60 \%$. Ini artinya bahwa pelatihan yang dilakukan sudah bisa merubah habit masyarakat melalui praktek langsung.

3. Sampah organik merupakan potensi sumber daya yang dapat dikembangkan dengan mengolahnya menjadi kompos. Pengolahan sampah organik menjadi kompos dengan teknik bata terawang merupakan teknik yang simpel dan mudah dilakukan oleh masyarakat, untuk itu maka pelatihan ini dilakukan. Kompos yang dihasilkan dapat dimanfaatkan masyarakat untuk urban farming di rumah sendiri sehingga kebutuhan sayuran paling tidak untuk rumah sendiri dapat terpenuhi.

\section{Daftar Pustaka}

Ardiningtyas,Tri Ratna. 2013. Pengaruh Penggunaan EffectiveMicroorganism 4 (Em4) dan Molaseterhadap Kualitas Kompos dalamPengomposan Sampah OrganikRSUD

Dr. R. SoetrasnoRembang. Skripsi di Jurusan Ilmu Kesehatan MasyarakatFakultas Ilmu KeolahragaanUniversitas Negeri Semarang

Damanhuri, Enry. 2005. Some Principal Issues On Municipal Solid Waste Management In Indonesia. Department of Environmental Engineering - ITB

Kementrian PU. 2011. Desiminasi dan Sosialisasi Keteknikan Bidang PLP, Bidang Persampahan

Samekto, Riyo. 2006.Pupuk Kompos. Yogyakarta: PT. Citra Aji Parama.

Satori, Mohamad. 2003. Rancangan Sistem Industri Kecil Daur Ulang (IKDU) dalam Mewujudkan Sistem Pengelolaan Sampah Perkotaan Secara Terpadu. Program Magister Program Studi Pembangunan, ITB

Satori, Mohamad. 2014. Kajian Potensi Ekonomi Berbasis Sampah untuk Menumbuhkembangkan Ecopreneur dalam Mendukung Tamansari Ecovillage. BPLH Kota Bandung.

Tchobanoglous, George; Kreith, Frank. 2002. Handbook of Solid Waste Management (Second Edition). Mc Graw-Hill, New York

UU No18 tahun 2008 tentang Pengelolaan Sampah 